\title{
REPENSANDO AS NOÇÕES DE INFÂNCIA PARA A DOCÊNCIA EM ARTES
} VISUAIS

\author{
Juzelia de Moraes Silveira
}

DOI: $10.19179 / 2319-0868.804$ 


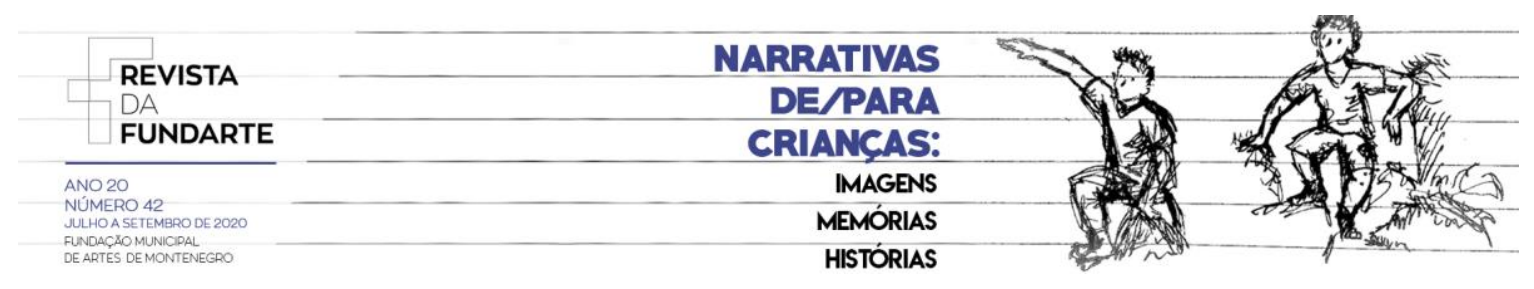

\title{
REPENSANDO AS NOÇÕES DE INFÂNCIA PARA A DOCÊNCIA EM ARTES VISUAIS
}

Juzélia de Morais Silveira ${ }^{1}$

Resumo: Desenvolvo esta escrita partindo de minhas experiências como docente de Artes Visuais e pautada pela perspectiva da Cultura Visual. Busco aqui discutir como construímos nossas concepções e discursos acerca das infâncias e de como é urgente compreender esta etapa da vida, tentando transcender velhos conceitos naturalizados sobre o tema. Ainda, partindo da premissa de que as crianças interagem de modo ativo com as visualidades que atravessam seus cotidianos, não apenas como consumidoras, mas também como produtoras, proponho uma reflexão sobre como desenvolvemos e podemos vir a desenvolver ações educativas, desde a Educação Infantil e Anos Iniciais do Ensino Fundamental, que convidem a pensar e problematizar as imagens que perpassam nossas vidas. Acredito que estas imagens atuam sobre as formas como vamos construindo nosso entendimento sobre o mundo e sobre nós mesmos.

Palavras-chave: Cultura Visual; Artes Visuais; Infâncias.

\section{RETHINKING CONCEPTIONS OF CHILDHOOD FOR VISUAL ARTS TEACHING}

\begin{abstract}
I develop this writing based on my experiences as a Visual Arts teacher and guided by the perspective of Visual Culture. I am here to discuss how we construct our conceptions and discourses about childhood and how urgent it is to understand this stage of life trying to transcend old naturalized concepts on the subject. Moreover, based on the premise that children interact in na active way with the visualities that cross their daily lives, not only as consumers, but also as producers, I propose a reflection on how we develop and can develop educational actions, from Early Childhood Education and Initial Years of Elementay School, which invite us to think and problematize the images that permeate our lives. Comprising that these images act on the ways we are building our understanding of the world and about ourselves.
\end{abstract}

Keywords: Visual Culture; Visual Arts; Chilhoods.

\footnotetext{
1 Doutora pelo Programa de Pós-Graduação em Arte e Cultura Visual - FAV/UFG. Bolsista REUNI - CAPES (2011-2015). Mestre em Artes Visuais pela UFSM/RS. Possui Graduação em Desenho e Plástica - Artes Visuais - Bacharelado (2004) e Graduação em Artes Visuais - Licenciatura Plena (2006), ambas pela UFSM/RS. Bolsista PDSE - CAPES (Programa Institucional de Bolsas de Doutorado Sanduíche no Exterior), com estágio no programa de Doctorado en Artes y Educación, da Universidad de Barcelona/ES (2013-2014). Professora substituta do curso de Artes Visuais . Licenciatura Plena, da UERGS/RS - Montenegro.
}

SILVEIRA, Juzélia de Morais. Repensando as noções de infância para a docência em artes visuais. Revista da FUNDARTE. Montenegro, p.01-21, ano 20, № 42, julho/setembro de 2020.

Disponível em: http://.seer.fundarte.rs.gov.br/index.php/RevistadaFundarte/index> 30 de setembro de 2020 


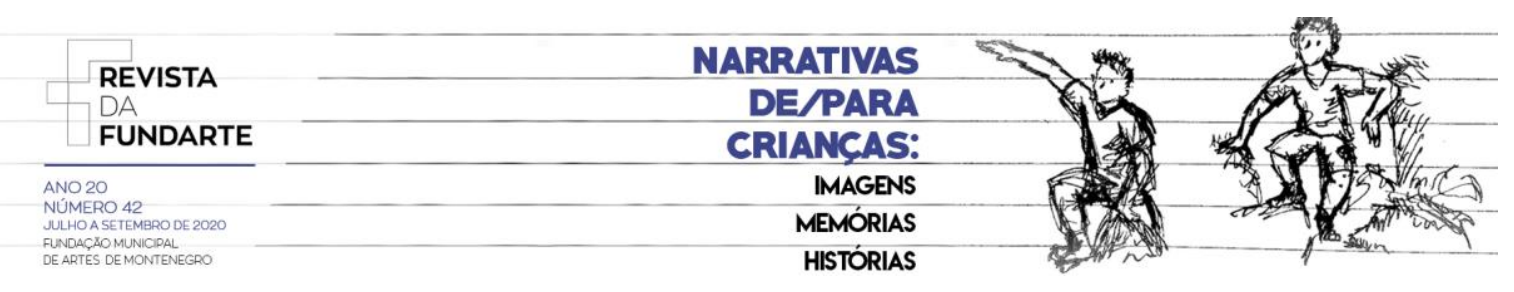

\title{
REPENSER LES NOTIONS D'ENFANCE POUR L'ENSEIGNEMENT DANS LES ARTS VISUELS
}

\begin{abstract}
Résumé: Je fais ce récit à partir de mes expériences en tant que professeur d'Art Visuel et basé sur la perspective de La Culture Visuelle. Je cherche ici à discuter comment nous construisons nos conceptions et nos discours à propos de l'enfance et comment est-ce urgent de comprendre cette étape de la vie, tout en essayant detranscender des vieilles conceptions naturalisées à propos du thème. Partant de la prémisse que les enfants interagissent de façon active avec les images qui traverssent leurs quotidiens, pas seulement en tant que consommateurs, mais aussi en tant que producteurs, je propose une réflexion sur le développement actuel et à venir des actions éducatives, dès la maternelle et les premières années de l'école primaire, actions qui nous invitent à penser et à questionner les images qui traverssent nos vies. Je crois que ces images agissent sur la façon dont nous construisons notre compréhension sur le monde et sur nous mêmes.
\end{abstract}

Mots Clés: Culture Visuelle; Arts Visuels; Enfances.

\section{Infâncias intraduzíveis e o desejo teimoso de tentar traduzi-las}

É difícil pensar uma escrita que se proponha a discutir as infâncias e que não caia em concepções e afirmativas românticas sobre elas. Não falo sobre as afirmativas pautadas em uma ideia ingênua de que as infâncias são envoltas por uma aura fantástica de felicidade plena. Falo sobre como é difícil não nos arrebatarmos com a capacidade que as infâncias nos provocam de espantar, maravilhar, surpreender, chocar. Falo desta característica de constantemente desestabilizar o que acreditamos apreender no entendimento acerca delas. Nisto, das questões mais surpreendentes que envolvem as discussões sobre o tema, reside o fato de que ao falarmos de infâncias, nos colocamos falando do outro, daquele que já não somos e que com dificuldade conseguimos acessar novamente a partir de nossas memórias. Por vezes quase parece nos escapar a noção de que um dia compusemos algum tipo destas inúmeras infâncias existentes.

Das discussões sobre infância que vivenciei em âmbito acadêmico, sempre relembro a fala de um professor que discorria sobre a nossa ânsia e tentativa vã de entender o que pensam e sentem aqueles que fazem parte de uma geração distinta da nossa. Mais grave do que isso, nossa tentativa de afirmar o que pensam e sentem tendo como parâmetro nossas vivências de tempos vividos, com nossas

SILVEIRA, Juzélia de Morais. Repensando as noções de infância para a docência em artes visuais. Revista da FUNDARTE. Montenegro, p.01-21, ano 20, no 42, julho/setembro de 2020.

Disponível em: http://.seer.fundarte.rs.gov.br/index.php/RevistadaFundarte/index> 30 de setembro de 2020 


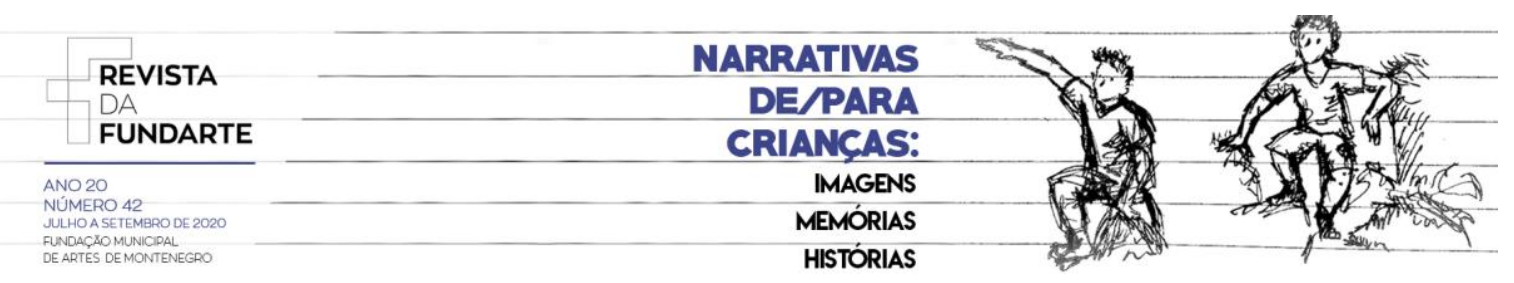

lentes do passado. Ocorre que ao passo que mudam os afetos, aquilo que nos atravessa diariamente, mudam também os modos de ser. Logo, não saberemos dizer as infâncias de agora, pois não somos nós quem as vivemos.

Entretanto, não nos abstemos de tentar conceituar esta etapa da vida, de representá-la a partir de nossa ótica, de discorrer sobre suas necessidades e fragilidades, colocando-nos assim como responsáveis por seu zelo e sucesso futuro. A respeito disso, nos diz Jorge Larrosa que

\begin{abstract}
A infância é algo que nossos saberes, nossas práticas e nossas instituições já capturaram: algo que podemos explicar e nomear, algo sobre o qual podemos intervir, algo que podemos acolher. A infância, desse ponto de vista, não é outra coisa senão o objeto de estudo de um conjunto de saberes mais ou menos científicos, a coisa apreendida por um conjunto de ações mais ou menos tecnicamente controladas e eficazes, ou a usuária de um conjunto de instituições mais ou menos adaptadas às suas necessidades, às suas características ou às suas demandas. (LARROSA, 2006, p.184).
\end{abstract}

Criamos um enorme aparato para pensar, discutir e definir a infância e, diante de tudo isso, reforçarmos nosso auto-entendimento como seus conhecedores e, consequentemente, reiteramos a incumbência de seu cuidado. E se por um lado, de fato cabe significativamente a nós, adultos, o cuidado para com estes sujeitos, também cabe um olhar mais amplo sobre o que constitui essas infâncias que já não são mais as nossas. Infâncias que se formam a partir de afetos diversos e distintos aos que nos afetaram, modos de interação com um mundo que já não é mais aquele em que nós vivemos esta fase da vida.

Por certo que não se trata de uma tarefa fácil tentar entender estes sujeitos sem sermos tomados pelos graus de superioridade que ganhamos ao passo em que nos tornamos adultos. Por isso, acredito que se trata, antes de mais nada, de uma questão de respeito com as experiências que o outro vivencia (tenha ele a idade que tiver), entendendo cada uma destas experiências como única e carregada de sentido para aquele que a vive.

SILVEIRA, Juzélia de Morais. Repensando as noções de infância para a docência em artes visuais. Revista da FUNDARTE. Montenegro, p.01-21, ano 20, no 42, julho/setembro de 2020.

Disponível em: http://.seer.fundarte.rs.gov.br/index.php/RevistadaFundarte/index $>30$ de setembro de 2020 


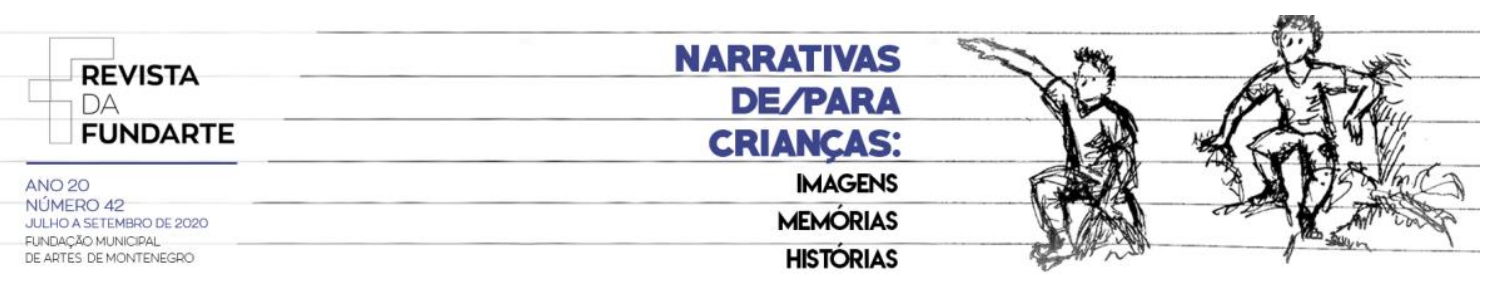

Esta postura também caminha ao lado do entendimento de que as crianças não são sujeitos passivos dentro do contexto sociocultural, mas também produtoras deste em significativa medida. Para Pinto e Sarmento

A consideração das crianças como actores sociais de pleno direito, e não como menores ou como componentes acessórios ou meios da sociedade dos adultos, implica o reconhecimento da capacidade de produção simbólica por parte das crianças e a constituição das suas representações e crenças em sistemas organizados, isto é, em culturas. (1997, p. 19).

Compreendo que pensar e problematizar como as culturas infantis se constituem, como as crianças interagem com aquilo que está a sua volta consumindo e produzindo bens culturais, constitui parte do estudo que os educadores devem buscar a fim de desenvolver uma prática educativa mais coerente com as necessidades e interesses deste público. Para tanto, me parece fundamental que para que esta prática se desenvolva haja um exercício constante de escuta atenta e diálogo efetivo.

Ao longo de minha trajetória como docente de Artes Visuais, significativamente pautada na perspectiva da cultura visual, busco exercitar constantemente esta proposta em minha prática docente e isto tem sido de grande valia não apenas para os trabalhos que desenvolvo com o público infantil, mas vem ainda ajudando muito em meu trabalho atual, na formação de professores de um curso de Licenciatura em Artes Visuais. Somando-se a estas questões, procuro traçar meu trabalho como professora aliada à perspectiva da Cultura Visual, que de acordo com Hernández tem por um de seus maiores objetivos contribuir "para que os indivíduos fixem as representações sobre si mesmos e sobre o mundo e sobre seus modos de pensar-se. A importância primordial da Cultura Visual é mediar o processo de como olhamos e como nos olhamos, e contribuir para a produção de mundos". (2000, p.52)

Pensar modos de promover uma educação significativa a partir da Cultura Visual implica em refletir sobre como podemos efetivar esta proposta educativa dentro do âmbito escolar, mas também evidencia a importância da construção

SILVEIRA, Juzélia de Morais. Repensando as noções de infância para a docência em artes visuais. Revista da FUNDARTE. Montenegro, p.01-21, ano 20, no 42, julho/setembro de 2020.

Disponível em: http://.seer.fundarte.rs.gov.br/index.php/RevistadaFundarte/index> 30 de setembro de 2020 


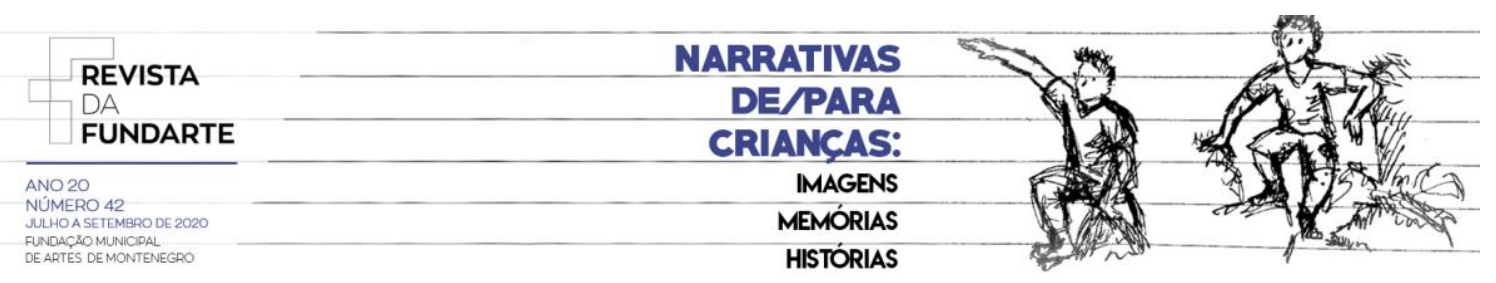

destes olhares na formação de professores. Na sequência me dedico a relatar como se deu este processo de aprendizagem ao longo dos anos e de como isto tem fortalecido meu trabalho com futuros educadores.

\section{Necessidades e possibilidades para o trabalho docente com crianças a partir da Cultura visual}

Nas primeiras experiências como docente tive a oportunidade de trabalhar com crianças da Educação Infantil e, posteriormente, das séries iniciais do Ensino Fundamental. Ainda totalmente envolta pelos estudos inspiradores realizados na graduação, tinha a pretensão de tornar aquelas crianças "crítico-reflexivas" diante de seus contextos de vida. Conservo comigo o desejo e a tentativa de propiciar que as crianças observem e pensem sobre o que está ao seu redor. Todavia, aprendi com elas a tentar, antes de mais nada, ver aquilo que veem e o que desejam me mostrar, pois é assim que tenho as pistas para saber o que vivem, desejam, pensam, entendem, acreditam... E com isso, consigo saber como posso, como educadora, ensinar algo que faça sentido para suas vidas.

Talvez isso possa sugerir uma falsa ideia de que a abordagem dos conteúdos próprios das Artes Visuais fica em segundo plano em minha prática docente. A verdade é que ao longo dos anos eles têm feito cada vez mais sentido como temas pertinentes a serem ensinados, mas isto principalmente porque o sentido da abordagem pedagógica não parte, a priori, dos conteúdos para as relações com os contextos e sujeitos com os quais são desenvolvidos. Mas o contrário: minha prática pedagógica nutre-se principalmente daquilo que os alunos me mostram, narram e sugerem de suas vidas e de seus cotidianos.

Isto significa uma tentativa constante de estar aberta a tudo que está presente no contexto educativo e no que os alunos me apresentam mas que, por muitas vezes, meu olhar adulto estranha. Este olhar tende a demonstrar certa insensibilidade a algumas sutilezas que as crianças percebem com facilidade.

SILVEIRA, Juzélia de Morais. Repensando as noções de infância para a docência em artes visuais. Revista da FUNDARTE. Montenegro, p.01-21, ano 20, № 42, julho/setembro de 2020.

Disponível em: http://.seer.fundarte.rs.gov.br/index.php/RevistadaFundarte/index> 30 de setembro de 2020 


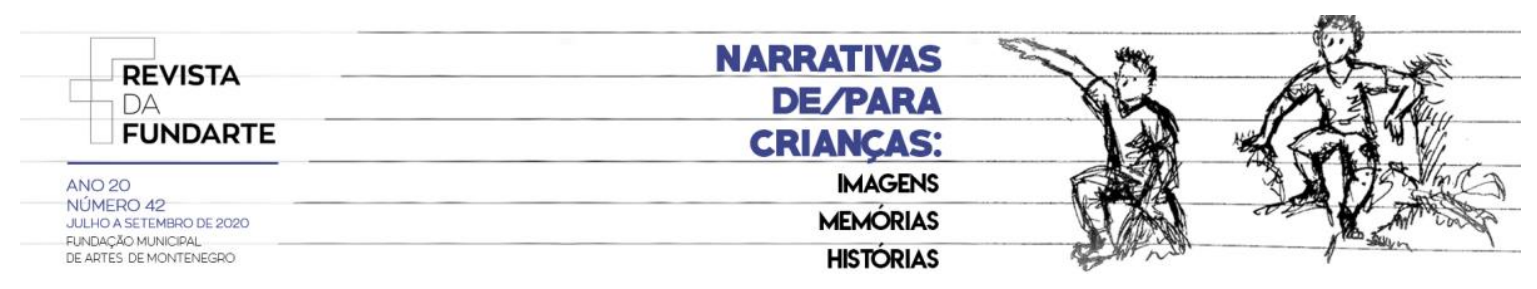

Acredito, sim, que também vamos aprendendo outras sutilizas ao longo da vida, entretanto, sempre me soa triste pensar na perda destas que são facilmente percebidas por uma ótica infantil.

Recordo um conhecido texto de Rubem Alves (1999) que fala sobre este olhar infantil que capta com mais facilidade aquilo que o olhar adulto já não percebe mais. Em uma parte da crônica "O olhar adulto" o autor narra uma passagem entre mãe e filha e sobre como, ao percorrem o mesmo caminho, tecem olhares distintos sobre aquilo que veem.

Os olhos da criança vão como borboletas, pulando de coisa em coisa, para cima, para baixo, para os lados, é uma casca de cigarra num tronco de árvore, quer parar para pegar, a mãe lhe dá um puxão, a criança continua, logo adiante vê o curiosíssimo espetáculo de dois cachorrinhos num estranho brinquedo, um cavalgando o outro, quer que a mãe veja, com certeza ela vai achar divertido, mas ela, ao invés de rir, fica brava e dá um puxão mais forte, aí a criança vê uma mosca azul flutuando inexplicavelmente no ar, que coisa mais estranha, que cor mais bonita, tenta pegar a mosca, mas ela foge, seus olhos batem então numa amêndoa no chão e a criança vira jogador de futebol, vai chutando a amêndoa, depois é uma vagem seca de flamboyant pedindo para ser chacoalhada, assim vai a criança, à procura dos que moram em todos os caminhos, que divertido é andar, pena que a mãe não saiba andar por não ter olhos que saibam brincar, ela tem muita pressa, é preciso chegar, há coisas urgentes a fazer, seu pensamento está nas obrigações de dona de casa, por isso vai dando safanões nervosos na criança, se ela conseguisse ver e brincar com os brinquedos que moram no caminho, ela não precisaria fazer análise...(ALVES, 1999, p. 13).

Ao longo da escrita o autor enfatiza que esta mãe, com os olhos já pouco curiosos e pouco sensíveis aos encantos da vida comum, aprendera a deixar de perceber as coisas também com sua mãe, para a qual a visão também já havia sido condicionada pelas obrigações da vida adulta. Com isso o autor aponta para o fato de que as maneiras como vamos aprendendo a perceber o mundo estão intrinsecamente ligadas ao modo como somos estimulados, ou não, a olhar para ele. As pessoas com as quais convivemos desde nossa infância, atuam significativamente sobre a construção de nossa visão sobre as coisas, sobre o

SILVEIRA, Juzélia de Morais. Repensando as noções de infância para a docência em artes visuais. Revista da FUNDARTE. Montenegro, p.01-21, ano 20, no 42, julho/setembro de 2020.

Disponível em: http://.seer.fundarte.rs.gov.br/index.php/RevistadaFundarte/index> 30 de setembro de 2020 


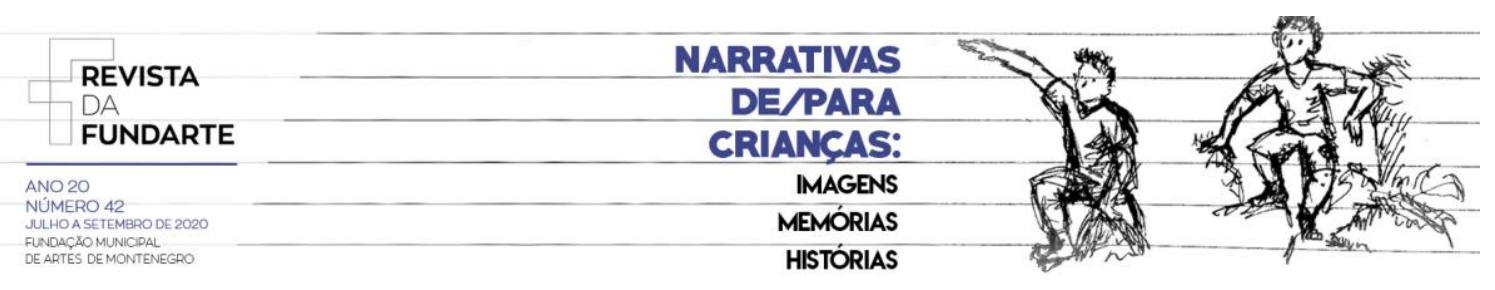

interesse que lançamos sobre estas. Neste processo está contido não apenas o incentivo do adulto para que se ampliem as possibilidades de descobertas infantis acerca do mundo, mas também a atenção deste adulto sobre o que o olhar sensível da criança capta e a escuta atenta sobre o que ela narra sobre o que vê.

$\mathrm{Na}$ experiência que tive com Educação Infantil e Anos Iniciais do Ensino Fundamental este olhar sensível ${ }^{2}$ das crianças se manifestava em inúmeros momentos do cotidiano escolar. Olhares demorados e curiosos sobre insetos e pássaros; ponderações reflexivas sobre a origem do leite (caixinha ou vaca?); discussões intensas sobre onde, afinal, mora Deus; debates acalorados sobre quem é mais forte na disputa entre homens e mulheres.

As perguntas aparentemente tolas ou ingênuas começaram a provocar, com frequência, uma análise mais demorada. E começaram a mostrar outras possibilidades de respostas e verdades menos automáticas e mais coerentes com os contextos de onde emergiam as perguntas. A formulação das perguntas evidenciava aprendizagens desenvolvidas significativamente fora da escola, no contato familiar, nas redes de amizades, nas coisas que consumiam em jogos ou TV. De mesmo modo sugeriam possibilidades pedagógicas a partir do Ensino de Arte e da perspectiva da Cultura Visual.

Trago uma fala de Hernández (2000) para explicitar como a perspectiva da Cultura Visual propõe o diálogo entre os saberes formais desenvolvidos dentro da escola em relação à vida cotidiana, principalmente indagando sobre como as representações visuais, constroem compreensões e versões acerca das realidades vividas.

[...] diante da cultura visual não há receptores nem leitores, mas construtores e intérpretes na medida em que a apropriação não é passiva nem dependente, mas interativa e de acordo com as experiências que cada

2Uso o termo "sensível" buscando não o sentido romântico da palavra, que pode ser facilmente
interpretado neste contexto como "doce" ou mesmo, "meigo". Busco mais a noção daquilo ou daquele
que se apresenta significativamente aberto e facilmente receptivo às coisas com as quais interage de
alguma maneira. Inclusive porque este sentido não esbarra também na ideia de ingenuidade, mas
volta-se para a capacidade de se permitir ser tocado pelas coisas para, assim, tentar compreendê-las.

SILVEIRA, Juzélia de Morais. Repensando as noções de infância para a docência em artes visuais. Revista da FUNDARTE. Montenegro, p.01-21, ano 20, no 42, julho/setembro de 2020.

Disponível em: http://seer.fundarte.rs.gov.br/index.php/RevistadaFundarte/index> 30 de setembro de 2020 


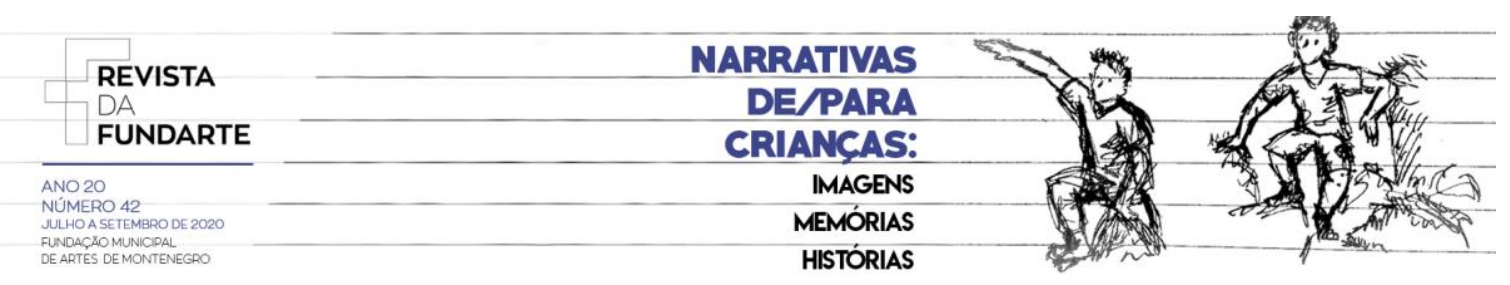

indivíduo tenha experimentado fora da escola. Daí a importância, a posição de ponte que a cultura visual exerce: como campo de saberes que permite conectar e relacionar para compreender e aprender, para transferir 0 universo visual de fora da escola (do aparelho do vídeo, dos videoclipes, das capas de CD, da publicidade, até a moda e o ciberespaço etc.) com a aprendizagem de estratégias para decodificá-lo, interpretá-lo e transformá-lo na escola. (HERNÁNDEZ, 2000, p. 52).

As representações sociais construídas por meio das visualidades cotidianas, por certo não afetam somente os adultos. As crianças estão constantemente em diálogo com um universo de imagens amplo e que sugere papéis sociais, comportamentos, modos de ver e pensar os outros e a si mesmas. Entretanto, é importante ter em vista que estas crianças constroem opiniões sobre estas visualidades com as quais convivem. $\mathrm{E}$, ainda que os meios publicitários voltados ao público infantil possuam alto caráter apelativo e sedutor, a interação com estes não deixa de lado tudo aquilo que sabem e aprendem em outros âmbitos de suas vidas. Neste sentido, a ótica da Cultura Visual, ao entender que todos somos intérpretes daquilo que consumimos visualmente, reforça a concepção sobre a importância de promover estes espaços de discussão sobre as imagens que atravessam nossas vidas, desde a mais tenra idade.

Crianças, seja da Educação Infantil ou das Séries Iniciais, observam seus contextos, pensam sobre estes, posicionam-se frente ao que veem no seu dia a dia, argumentam sobre o que veem e podem, inclusive, colocar-se de modo contrário ao que nós, adultos, sugerimos ou acreditamos. E obviamente isto tudo é condicionado e afetado pelas coisas que fazem parte de seus universos infantis, pois as lentes utilizadas para ver e pensar o mundo são oriundas deste universo, entretanto, isso não significa um olhar limitado e alheio ao contexto social, porque "as culturas infantis não nascem no universo simbólico exclusivo da infância, este universo não é fechado - pelo contrário, é, mais do qualquer outro, extremamente permeável nem Ihes é alheia a reflexividade social global". (PINTO; SARMENTO, 1997, p.22)

SILVEIRA, Juzélia de Morais. Repensando as noções de infância para a docência em artes visuais. Revista da FUNDARTE. Montenegro, p.01-21, ano 20, № 42, julho/setembro de 2020.

Disponível em: http://.seer.fundarte.rs.gov.br/index.php/RevistadaFundarte/index> 30 de setembro de 2020 


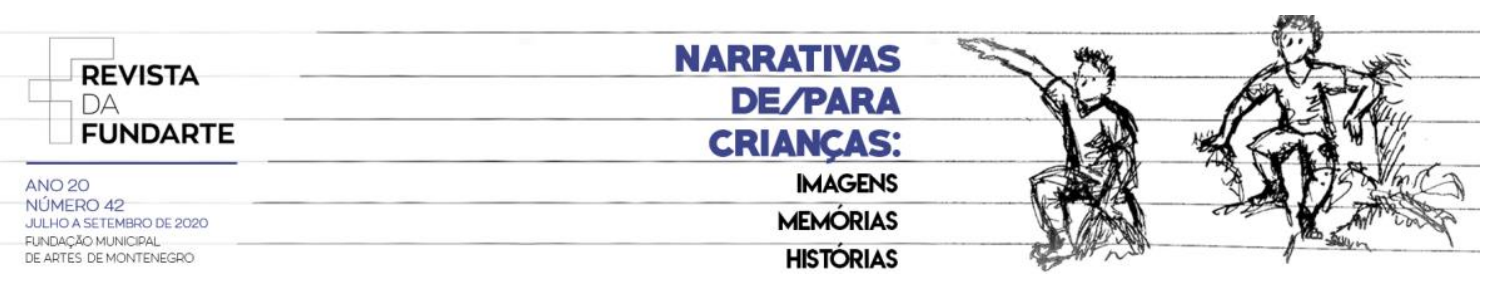

Somando-se às perguntas e discussões travadas entre as crianças que presenciei em minha prática educativa, percebia também nos atos cotidianos e modos de estabelecer relações com os outros e com os espaços vividos, fontes riquíssimas de informações sobre o meu público alvo. Nas brincadeiras realizadas no dia a dia era possível perceber a incorporação de códigos, ações e referências extraídas daquilo que vivenciavam nos diversos locais pelos quais circulavam e também, a partir do que observavam dos meios de interação estabelecidos entre pessoas e também a partir do contato com aquelas com as quais se relacionavam de alguma forma.

$\mathrm{O}$ ato de brincar, deste modo, se apresenta como reflexo daquilo que é visto e vivido em cada contexto, se desdobra a partir destas referências. Isto reforça a compreensão de que esta atividade não é inata, pois, "não existe na criança uma brincadeira natural, a brincadeira é um processo de relações interindividuais, portanto, de cultura" (BROUGĖRE, 2001, p. 97). Sendo assim, a brincadeira engendra inúmeros processos de negociação, de tomada de decisões, de estabelecimento de regras, de afirmação de posturas, de incorporação de personalidades. E tudo isto emerge do que é percebido no cotidiano e, de algum modo, interpretado pela criança.

Todavia, se não se trata de uma incorporação passiva. E neste sentido a brincadeira se mostra como um valiosíssimo meio de aprendizagem. Pois, o fato de a brincadeira possibilitar a vivência de papéis diversos no jogo da fantasia, permite também pensar tais papéis e a complexidade do que os compõe. Ao interpretar papéis sociais diversos, durante 0 ato de brincar, a criança constrói sua representação a partir do que conhece e das referências que the foram ensinadas sobre determinado personagem da vida social. Entretanto, inserida no mundo da fantasia, onde a criação de outros modos de ser é permitida, elabora maneiras mil de viver os espaços, inventando outras combinações sociais. Sendo assim, a brincadeira não se configura necessariamente como um lugar de reprodução daquilo que foi aprendido, mas como possível espaço de experimentação e invenção. 


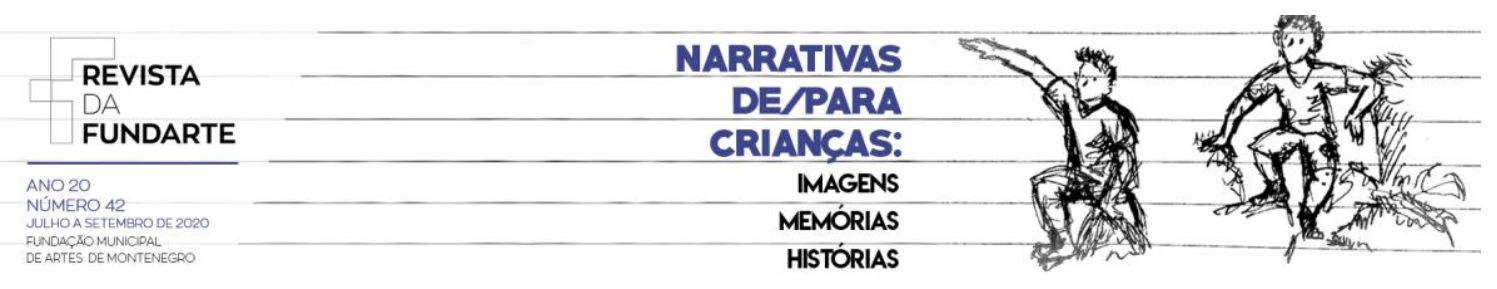

Retomando a assertiva de que as crianças constroem seus olhares e suas opiniões sobre o mundo a partir do que observam em seu entorno, e de que somado a isto, apresentam-se curiosas diante deste mundo e significativamente abertas ao diálogo, promover espaços para que estes papéis sociais sejam pensados é uma maneira de buscar desenvolver aprendizagens para além da abordagem de conteúdos escolares formais, comumente desconectados das vidas reais e contextos específicos. Mas justamente buscar uma educação que proponha colocar as verdades em suspenso, questioná-las, observá-las por vieses diversos a fim de construir, desde cedo, opiniões próprias sobre as coisas do mundo.

Tomando como premissa que a brincadeira é uma importante atividade desenvolvida por crianças no desenvolvimento de suas compreensões acerca do mundo e para suas construções enquanto sujeitos sociais, e ainda, que o ato de brincar é mediado por aquilo que a criança percebe do que está a sua volta, cabe aqui uma atenção àquilo que é consumido visualmente por estas, observando as diversas referências imagéticas que circundam seus cotidianos. Personagens que transitam por suas rotinas estampadas em camisetas, mochilas, brinquedos, fazendo-se presença constante em suas vidas. Desenhos animados, filmes e jogos que, a partir de seus universos de fantasia, narram histórias que atravessam as concepções que as crianças constroem acerca do mundo. Visualidades que dialogam com as cenas reais cotidianas vividas em família, entre amigos, na vida escolar.

Observando isto, me propus a desenvolver algumas propostas pedagógicas que partissem e problematizassem algumas questões oriundas destas visualidades produzidas para o público infantil. Em uma de minhas aulas com uma turma de primeiro ano do ensino fundamental, trabalhei com os alunos algumas obras da artista Dina Goldstein, da série Fallen Princesses. Dentre estas, abordei principalmente a obra Snowy (2008). 

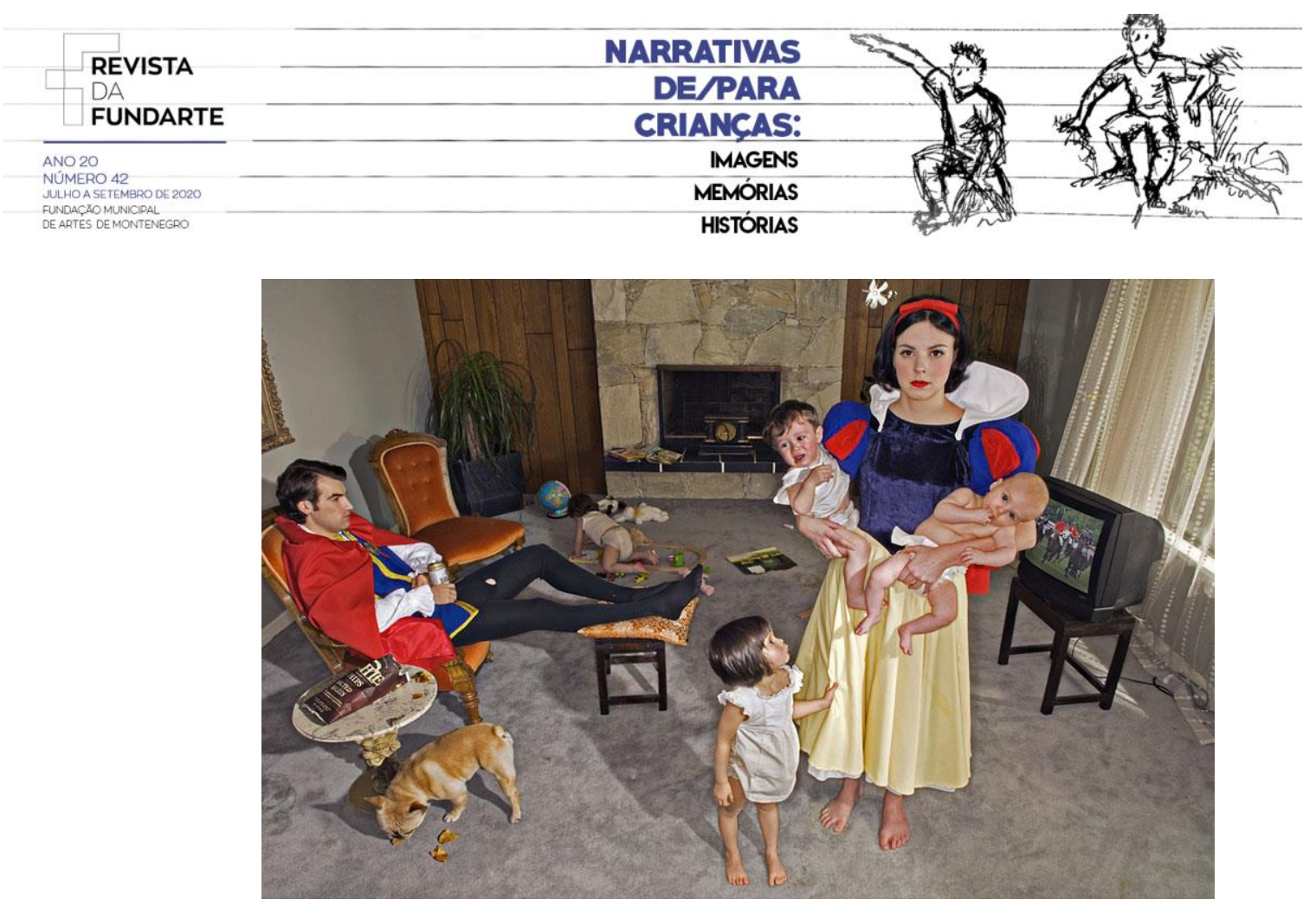

Imagem 1: Dina Goldstein. Snowy. (2008). (Fonte: www.dinagoldstein.com)

As perguntas iniciais para a abordagem da obra foram simples e, posteriormente, acabaram dando lugar às observações intensas e interpretações múltiplas dos alunos. De início, a grande maioria identificou os personagens presentes na cena. Riram com os aspectos inusitados, como a presença de supostos filhos nos braços da Branca de Neve, de um cachorro que come os petiscos caídos no chão, com o fato do príncipe estar segurando o que eles identificaram como uma cerveja (este último fato, inclusive interpretado a partir das vivências familiares).

Perguntei aos alunos se possuíam irmãos pequenos e sobre quem era 0 responsável pelos cuidados com estes irmãos. Muitos responderam que suas mães eram as principais responsáveis. Contudo, muitos também mencionaram suas avós, irmãos mais velhos e até mesmo que eles, em algum momento, acabavam tendo como tarefa o cuidado dos irmãos mais novos. Conversamos sobre as noções de cuidado, de responsabilidade, de dever, pois a abordagem da obra escolhida não precisava limitar-se ou centrar-se na questão dos distintos papéis desempenhados por homens e mulheres nas relações sociais. Prova disto é o fato de que nas relações de cuidado com o outro nas relações familiares citadas em aula, alguns alunos citaram a si mesmos como responsáveis pelos irmãos. 


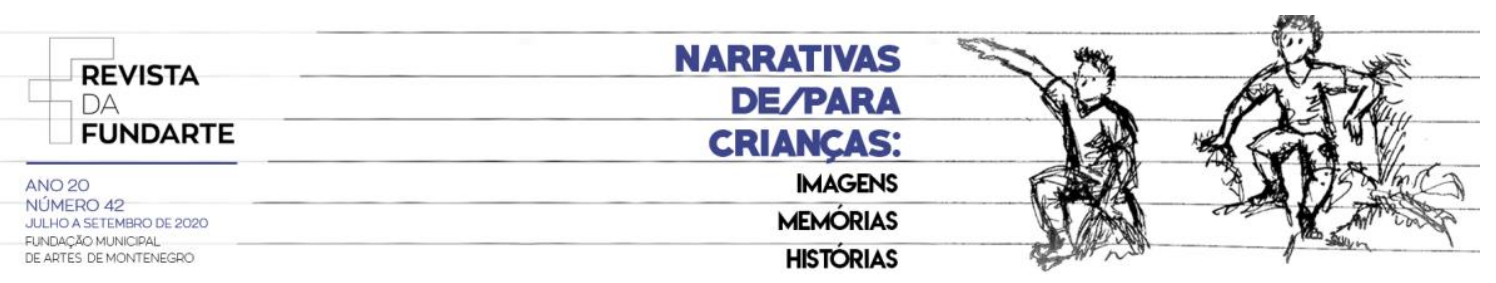

Sendo assim, a proposta buscava muito mais pensar, a partir da realidade vivida por aqueles alunos, os papéis possíveis a serem desempenhados por cada um, em cada estrutura familiar. Isto, indo além do "viveram felizes para sempre", sugerido pelo conto da Branca de Neve, mas sem deixar de lado a possibilidade de uma vida feliz, construída a partir das negociações estabelecidas entre pessoas que convivem, em que as necessidades e responsabilidades são pesadas respeitando cada pessoa.

Após o longo debate, foi proposto aos alunos que, para o desenvolvimento de trabalhos práticos, tivessem como ponto de partida as seguintes questões: $O$ que será que acontece depois que o príncipe beija a Branca de Neve? Será que poderia haver outra possibilidade de futuro para os dois personagens, diferente do que sugere a artista? Quem seriam vocês nesta história? O que fariam nesta história? Com isso, busquei dar continuidade ao processo reflexivo sobre o tema, mas agora, propondo aliar as questões que surgiram na discussão, à criação de outras possibilidades, distintas da cena sugerida pela artista. Sendo assim, foi sugerida a utilização da linguagem do desenho (pensando sobretudo o desenho de ilustração), buscando referências em livros infantis trabalhados em aulas de outras professoras, assim enfatizando também a importância das linguagens visuais na produção de narrativas diversas.

De acordo com o que Derdyk (2015, p. 117) afirma sobre a prática do desenho na infância, esta atividade "conjuga elementos oriundos do domínio da observação sensível do real e da capacidade de imaginar e projetar, vontades de significar. $O$ desenho configura um campo minado de possibilidades, confrontando 0 real, o percebido e o imaginário". Isso significa que o ato de desenhar é totalmente conectado com o pensamento e que este pensamento aliado à imaginação, expande a possibilidade de invenção de situações mil, podendo assim, intensificar a reflexão sobre seu mundo real, sonhando outros contextos possíveis, modos de ser diversos. Assim, ampliando sua visão sobre si mesmo, sobre o outro e sobre o espaço que habita.

SILVEIRA, Juzélia de Morais. Repensando as noções de infância para a docência em artes visuais. Revista da FUNDARTE. Montenegro, p.01-21, ano 20, no 42, julho/setembro de 2020.

Disponível em: http://.seer.fundarte.rs.gov.br/index.php/RevistadaFundarte/index> 30 de setembro de 2020 


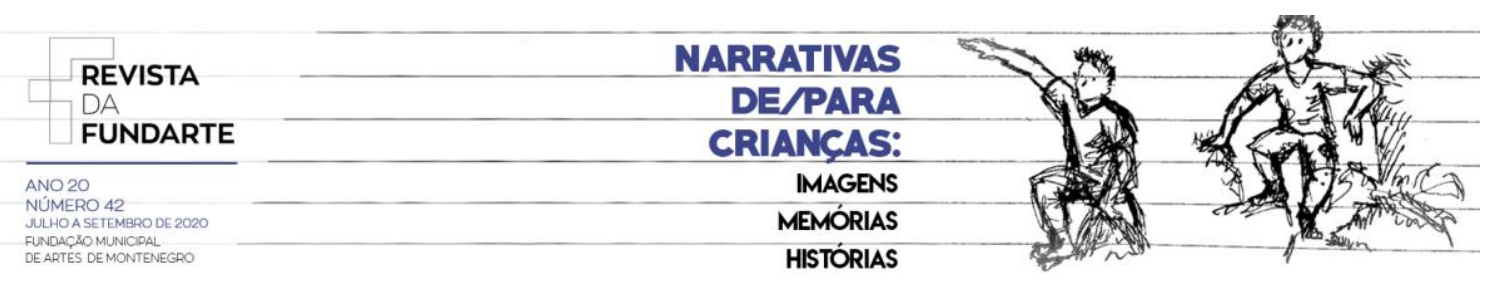

Infelizmente o que se vê comumente sendo desenvolvido com as crianças no contexto escolar ainda se distancia muito desta proposta de ensino de arte. Isto traz à tona uma perspectiva de ensino que não compreende a importância de um conhecimento da arte que vá além das meras informações sobre nomes de artistas e obras, que não compreende o fazer também como um pensar. Tampouco esta perspectiva entende a relevância de que o ensino de arte não mais se limite à abordagem de obras de arte legitimadas, mas que traga para a discussão as imagens que percorrem as vidas dos alunos. Por fim, a este entendimento limitado sobre o ensino de arte, soma-se o preconceito acerca da capacidade de posicionamento crítico das crianças frente ao que veem, o que acaba por impulsionar propostas educativas que promovem poucos desafios aos alunos e que reforçam uma ideia de que são somente receptores de informações fornecidas pelos educadores.

Entendo que um dos passos para a resolução deste problema deva iniciar nos cursos de formação de professores de Artes Visuais, ampliando discussões sobre as infâncias, buscando transcender o olhar tradicional comumente tecido sobre estas. De mesmo modo, percebo a urgência de também ampliar a perspectiva do Ensino de Arte a partir dos diálogos com a Cultura Visual, compreendendo que as visualidades que transitam por nossas vidas são carregadas de informações e discursos que dialogam com os modos como vamos construindo nossos olhares sobre o mundo.

Como mencionei anteriormente, todas estas aprendizagens que tive ao longo de minha experiência com a Educação Infantil e Ano Iniciais do Ensino Fundamental têm me auxiliado também a pensar minhas ações na formação de professores. Para tanto, retomo com frequência aquilo que aprendi com as crianças para poder pensar, juntamente com meus alunos da graduação, estratégias de ensino para o público infantil que levem em conta estas especificidades da infância mencionadas ao longo do texto e o papel do Ensino de Arte na formação destes sujeitos. 


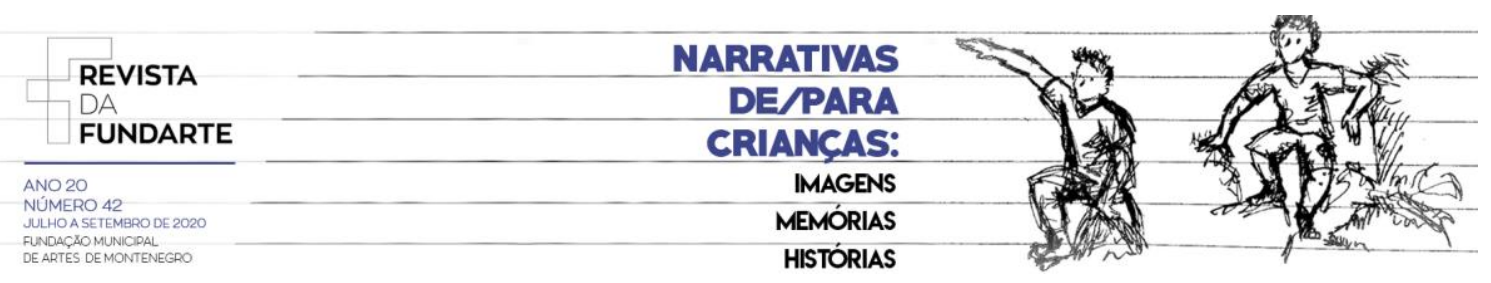

\section{A importância de desestabilizar conceitos sobre infâncias para}

\section{a formação docente}

No segundo semestre do ano de 2018 trabalhei com os alunos do curso de Licenciatura em Artes Visuais o capítulo "Elogio do Riso", do livro "Pedagogia profana - danças, piruetas e mascaradas", de Jorge Larrosa (2006). Entreguei o texto no início da aula e retornamos após uma hora para realizar a discussão sobre o que havia sido lido. Quando retornamos, percebi que os alunos estavam um pouco desconcertados com a leitura e, aos poucos foram demonstrando este abalo a partir de seus comentários.

O texto de Larrosa questiona sobre nosso pedestal de superioridade adulta, mas também acaba por provocar-nos sobre nossa responsabilidade para com as crianças. Ao longo do texto o autor insiste na ideia de um enigma da infância, do caráter inapreensível desta e também sobre o nosso desejo constante de tentarmos dominá-la. Nisto estão presentes os processos educativos desenvolvidos nas relações estabelecidas entre adultos e crianças; todavia, estes processos costumam possuir um sentido único, que parte dos ensinamentos do adulto para a criança, da lógica adulta acerca do que a criança necessita aprender sobre o mundo.

Compreendendo a educação como "o modo como as pessoas, as instituições e as sociedades respondem à chegada daqueles que nascem." (LARROSA, 2006, p. 188) o autor propõe um caminho distinto ao da tentativa de domínio e apreensão, buscando "abrir um espaço para que aquele que vem possa habitar; pôr-se à disposição daquele que vem, sem pretender reduzi-lo à lógica que impera na nossa casa" (LARROSA, 2006, p. 188). Este sentido educativo não se limita à noção de um ensino formal, entretanto, acaba por provocar também a nós, educadores, uma busca de prática educativa que respeite as singularidades das infâncias, que esteja aberta às suas manifestações diversas e distintas da lógica adulta.

Esta foi uma das principais questões que deram suporte à discussão tecida com os adultos da graduação. Seguindo esta perspectiva, tentamos estabelecer nossas ideias pautados pelo entendimento de que não há uma infância, um modo de 


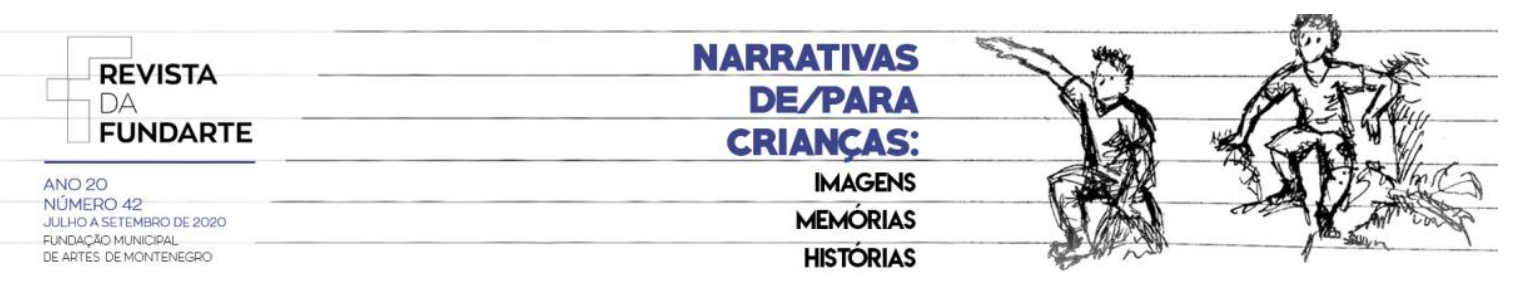

ser criança. Neste sentido, buscamos pensar quais são as imagens que dizem as infâncias, aquelas produzidas para as infâncias, os discursos que as circundam, aquilo que não é dito sobre elas, etc.

Construímos coletivamente mapas $^{3}$ sobre as infâncias, não com o intuito de delimitar fronteiras, mas para podermos ampliar nossos olhares para além do que estamos habituados a ver, perceber acerca delas. Nestes mapas estiveram presentes imagens que representaram as infâncias ao longo da história da arte, produzindo concepções acerca destas. Também compuseram os mapas algumas imagens publicitárias que narram infâncias, trazendo à tona suas estratégias de venda e sedução. Outros elementos presentes faziam referência a bens de consumo voltados a este público, como objetos, roupas, artefatos de ordens variadas. Ainda foram incluídos trechos de notícias diversas sobre crianças, fragmentos de livros infantis e até mesmo pedaços de artigos sobre infâncias utilizados ao longo da disciplina.

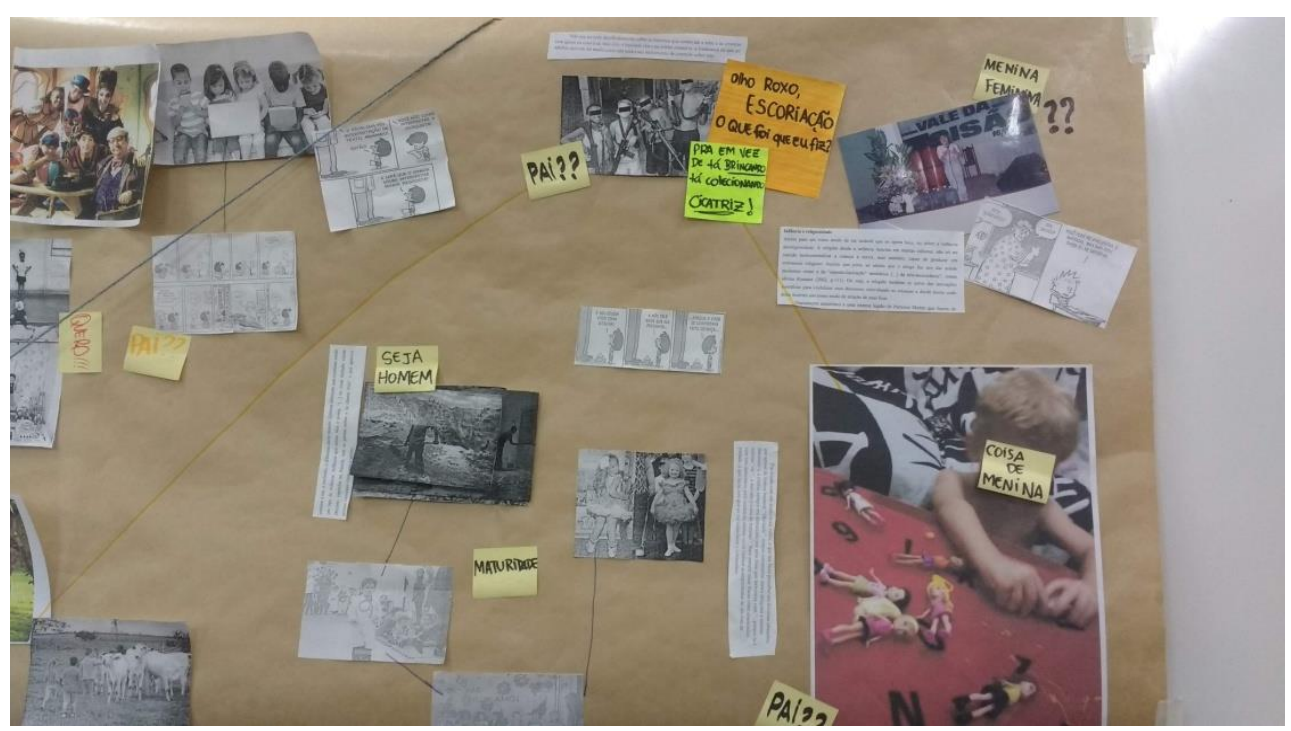

Imagem 2: Mapa construído na disciplina de Metodologia e Prática de Ensino I, 2018. (Fonte: autora)

\footnotetext{
${ }^{3}$ É importante mencionar que foram trabalhados em aulas anteriores alguns artigos referentes à abordagem metodológica da cartografia, os quais permitiram uma aproximação com alguns conceitos de "mapa", sobretudo quando pensados em relação à pequisa com imagens. Dentre estes artigos destaco "Cartografia: uma outra forma de pesquisar", de Luciano Bedin da Costa (ver em Revista Digital do LAV - Santa Maria - vol. 7, n.2, p. 66-77 - mai./ago.2014).
}

SILVEIRA, Juzélia de Morais. Repensando as noções de infância para a docência em artes visuais. Revista da FUNDARTE. Montenegro, p.01-21, ano 20, no 42, julho/setembro de 2020.

Disponível em: http://.seer.fundarte.rs.gov.br/index.php/RevistadaFundarte/index> 30 de setembro de 2020 

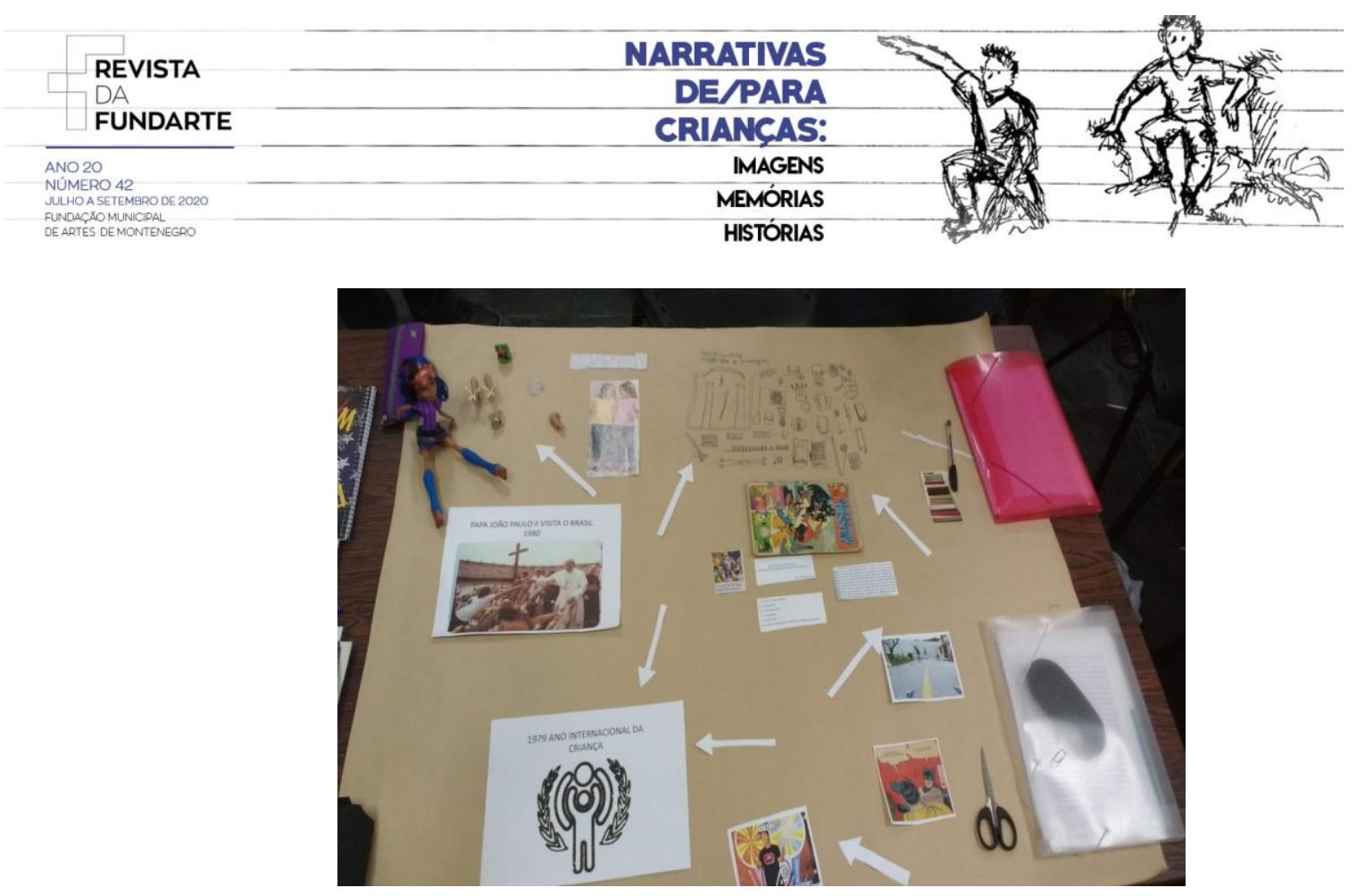

Imagem 3: Mapa construído na disciplina de Metodologia e Prática de Ensino I, 2018. (Fonte: autora)

Assim, conseguimos problematizar como as infâncias têm sido ditas e narradas e também, observar aquilo que fica de fora desta história, entendendo com isso que, de acordo com o que afirma Becker

Se a construção das identidades infantis está sujeita às práticas discursivas, elas podem se conhecer através dessas representações, fazendo com que essas apresentações e supressões se constituam em enunciados com mais discursos do que pode ser percebido no primeiro olhar. (2010, p. 91).

Isto aponta para a relevância das imagens na construção das infâncias e de discursos acerca desta, e também evidencia nosso papel como consumidores destas imagens, como impulsionadores e reprodutores destas representações.

Tentamos, assim, nos situarmos neste processo, expondo preconceitos que carregamos conosco, espantos diante das manifestações plurais das infâncias e nossas ações no processo de legitimação de discursos acerca delas. Fizemos isto tentando não perder de vista a conexão entre nossa área de conhecimento e nossas experiências cotidianas. Porém, agora buscando outra mirada para analisar aquilo que vivenciamos com crianças que fazem parte de nossas vidas.

O contato com textos que propõem um olhar menos romântico sobre nossas posturas frente às crianças, em que nos percebemos não somente como pessoas

SILVEIRA, Juzélia de Morais. Repensando as noções de infância para a docência em artes visuais. Revista da FUNDARTE. Montenegro, p.01-21, ano 20, no 42, julho/setembro de 2020.

Disponível em: http://.seer.fundarte.rs.gov.br/index.php/RevistadaFundarte/index> 30 de setembro de 2020 


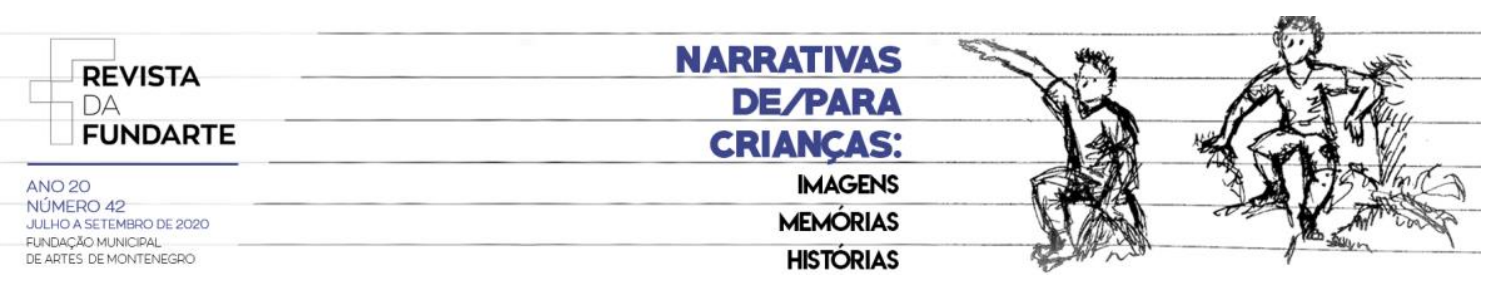

zelosas por elas, mas também como responsáveis por aquilo que as coloca em posição de inferioridade e fragilidade, acaba por provocar um potente mal-estar. Potente porque não nos mostra somente nossas tentativas de controle e nossa postura de superioridade, mas porque ao passo que vai nos apontando estes aspectos, vai sugerindo caminhos para que este ato de cuidado se efetive, sem deixar de lado o respeito para com as particularidades das vivências infantis.

Sendo assim, após as extensas leituras e discussões sobre infâncias, nos colocamos a pensar aspectos necessários a serem incluídos em nossas práticas docentes para podermos desenvolver o trabalho com crianças a partir do Ensino de Arte. Nisto, as problematizações da Cultura Visual estiveram presentes trazendo alguns pontos para reflexão, principalmente dando ênfase à importância da construção de um perfil docente implicado em conhecer aquilo que faz parte do universo dos alunos, aquilo que constitui seus interesses e desejos.

Diante desta perspectiva, compreendemos que devemos explorar juntamente com os alunos olhares questionadores frente às imagens com as quais nos deparamos, sejam elas produções artísticas, ou oriundas da mídia, das representações visuais diversas que transitam pelos cotidianos, ou ainda das cenas que vivenciamos nos espaços por onde passamos. Nisto, um dos principais aspectos deste posicionamento educativo consiste também em entender que todos (alunos e professores, crianças e adultos) somos suscetíveis ao que as imagens nos dizem, que estabelecemos diálogos com aquilo que vemos, isto, mediado pelas lentes que utilizamos para ver o mundo.

Logo, não podemos ignorar o caráter de prazer contido nas experiências visuais e nossos desejos de interação com aquilo que vemos. Por isso, a partir da proposta da Cultura Visual, o educador deveria pretender-se mais como um mediador na proposição de abordagem de imagens em sala de aula, ou, como propõe Hernández, "a postura do adulto deve ser a de moderador, buscando o equilíbrio entre o desfrute da experiência dos estudantes com os artefatos da cultura visual e a introdução de uma perspectiva crítica e performativa que signifique

SILVEIRA, Juzélia de Morais. Repensando as noções de infância para a docência em artes visuais. Revista da FUNDARTE. Montenegro, p.01-21, ano 20, no 42, julho/setembro de 2020.

Disponível em: http://.seer.fundarte.rs.gov.br/index.php/RevistadaFundarte/index> 30 de setembro de 2020 


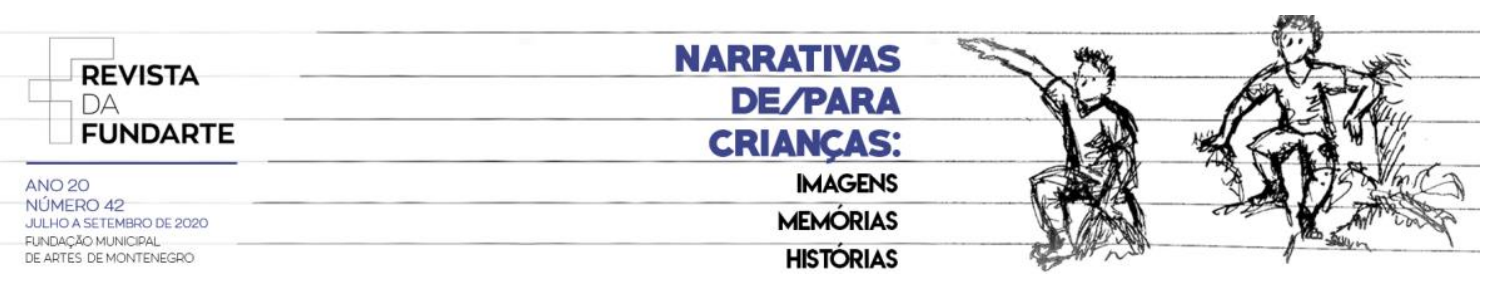

discussão, exploração, vivência" (2007, p. 88). Assim, o professor buscará uma proposta educativa que não ignorará as diversas formas com que os alunos se relacionam com aquilo que veem, e os aspectos envolvidos nesta interação, mas problematizará junto com seus alunos, como se dão estas interações, buscando construir, desde cedo, um entendimento destas imagens também como construtoras daquilo que somos e pensamos.

Isso vai ao encontro da ideia que propõem Pinto e Sarmento (1997) quando afirmam que as culturas infantis precisam ser observadas em relação aos contextos sociais nas quais se desenvolvem, fugindo a um olhar generalizante sobre o ser criança e compreendendo a importância desta análise para pensar como as crianças interagem, como compõem e interpretam seus espaços, como atuam sobre estes. Isto propõe uma ação docente que busque desenvolver estratégias pedagógicas para que estas crianças não sejam somente reprodutoras daquilo que thes é transmitido no dia a dia, mas que as incentive a indagarem o que veem.

Propus aos alunos que elaborassem práticas educativas que procurassem pôr em prática estas proposições discutidas em aula acerca do trabalho a ser realizado com crianças. Nestas propostas, esteve presente a atenção à ludicidade, porém, considerando a importância do brincar no universo infantil e não reduzindo este ato a um processo de fazer mecânico, mas em diálogo efetivo com a atividade planejada. Também esteve presente uma atenção às atividades práticas elaboradas, evidenciando o fazer como inseparável do pensar. Uma das questões que mais se evidenciou foi a preocupação em promover diálogos a partir dos temas selecionados para abordagem. Para tanto, foram pensados diálogos a partir de imagens não somente escolhidas pelos futuros professores, mas que procuravam nutrir-se dos artefatos visuais trazidos pelas crianças, presentes em seus contextos cotidianos e conectados com seus interesses pessoais. Isso evidenciou-se sobretudo nas propostas que partiram de discussões sobre brinquedos e brincadeiras, modos de brincar e como estes estão carregados de aprendizagens que dizem respeito a como a criança vê o mundo e o cria a partir de suas percepções. Assim, muitos

SILVEIRA, Juzélia de Morais. Repensando as noções de infância para a docência em artes visuais. Revista da FUNDARTE. Montenegro, p.01-21, ano 20, no 42, julho/setembro de 2020.

Disponível em: http://.seer.fundarte.rs.gov.br/index.php/RevistadaFundarte/index> 30 de setembro de 2020 


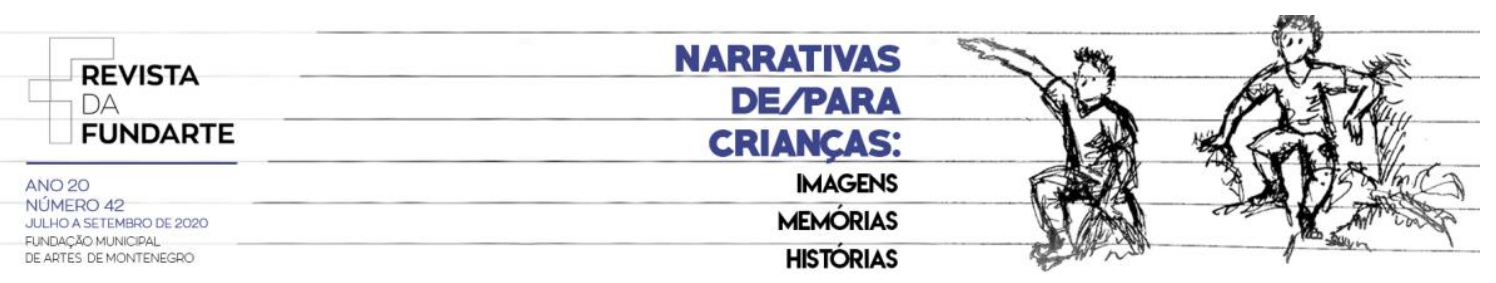

estudantes optaram por promover discussões partindo de brinquedos, tanto repensando seus usos como criando outros objetos lúdicos a partir das discussões. Ressalta-se ainda o movimento de alguns licenciandos de tentar conectar esses brinquedos efetivamente com questões culturais (como no caso de uma das propostas que partiu da história e da confecção de bonecas Abayomi - símbolo da cultura e resistência afro-brasileira), buscando ampliar o repertório dos alunos acerca da relação brinquedo/cultura.

Por fim, solicitei aos estudantes que realizassem uma escrita sobre as infâncias partindo das discussões tecidas em sala de aula e dos diálogos realizados com os autores. Mostraram que há muito a dizer sobre as infâncias, conjecturas a realizar sobre suas constituições, preconceitos a evitar sobre seus modos de ser, de aprender, de dizer o mundo. Felizmente presenciei em seus textos algumas tentativas de ir dissolvendo discursos já formatados, tentativas de pensar projetos educativos que respeitem as particularidades do universo infantil e que, a partir dessas, sejam desenvolvidas propostas coerentes com as necessidades e desejos destas crianças. Os alunos também sinalizaram procurar ver além daquilo que comumente se vê. E, para mim, todo esse movimento já é válido, pois demonstra a imersão em um processo de construção docente implicada em conhecer o outro, a ouvir o que diz, ao considerar seu contexto, para então, juntamente com ele, promover ações para o desenvolvimento de aprendizagens significativas.

Ser adulto é difícil, somos impulsionados a esquecer o que nos conectava com nosso ser criança. Somos incentivados (e posteriormente incentivamos outros) a narrar as infâncias como se as tivéssemos apreendido e como se fossem uma só. Por isso, a mínima tentativa de colocar-se aberto a aprender com as crianças já me parece um ato de grande maturidade. E aqui este termo não precisa estar relacionado com o substantivo "adulto", pois neste caso, para sermos mais maduros, mais experientes, precisamos aprender muito com as crianças. 


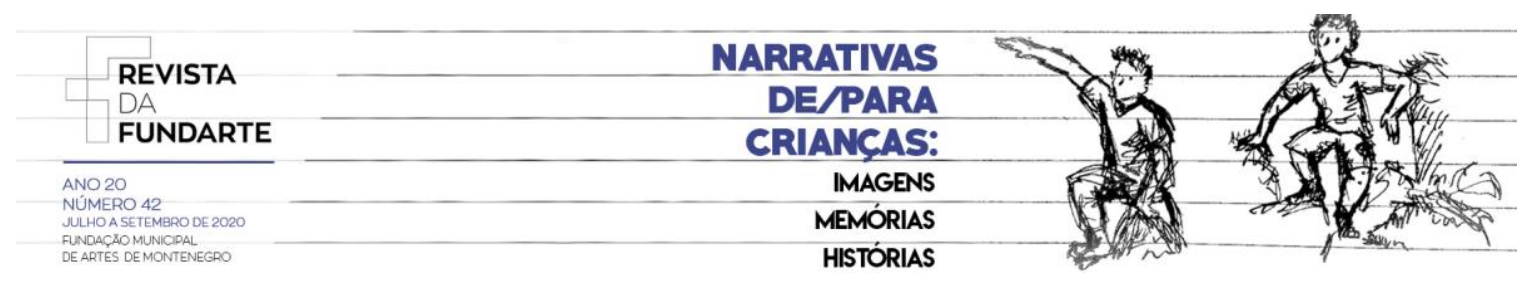

\section{Referenciais:}

ALVES, Rubem. O olhar adulto (A festa de Maria). Campinas: Editora São Paulo, 1999.

BECKER, Aline da Silveira, História e imagens: a visualidade produzindo infâncias. In: MARTINS, Raimundo; TOURINHO, Irene. Cultura Visual e Infância: quando as imagens invadem a escola. Santa Maria: ed. da UFSM, 2010.

BROUGÈRE, Gilles. Brinquedo e Cultura. São Paulo: Cortez, 2001.

DERDYK, Edith. Formas de pensar o desenho: Desenvolvimento do grafismo infantil. Porto Alegre: Zouk, 2015.

HERNÁNDEZ, Fernando. Cultura Visual, mudança educativa e projeto de trabalho. Porto Alegre: Artes Médica Sul, 2000.

HERNÁNDEZ, Fernando. Catadores da cultura visual: proposta para uma nova narrativa educacional. Porto Alegre: Editora Mediação, 2007.

LARROSA, Jorge. Pedagogia Profana: Danças, piruetas e mascaradas. Belo Horizonte: Ed. Autêntica, 2006.

PINTO, Manuel; SARMENTO, Manuel J. As crianças e a infância: definindo conceitos, delimitando o campo. In: PINTO, Manuel; SARMENTO, Manuel Jacinto. As crianças - contextos e identidades. Portugal, Centro de estudos da criança: Editora Bezerra, p.7-30, 1997.

SILVEIRA, Juzélia de Morais. Repensando as noções de infância para a docência em artes visuais. Revista da FUNDARTE. Montenegro, p.01-21, ano 20, no 42, julho/setembro de 2020.

Disponível em: http://.seer.fundarte.rs.gov.br/index.php/RevistadaFundarte/index> 30 de setembro de 2020 